Економічні науки: збірник наукових праиь Луиького національного технічного університету. - Серія "Регіональна економіка". - Випуск 16 (63). - Редкол.: відп. ред. д.е.н., професор Л.Л. Ковальська - Луцьк : ІВВ Луцького НТУ, 2019. -173 с.

УДК 332.12

Фесіна Ю.Г., к.е.н., доцент

Дзюбинська О.В., асистент

Луцький національний технічний університет

\title{
ПЕРСПЕКТИВИ ФОРМУВАННЯ ЦИКЛІЧНОЇ МОДЕЛІ ЕКОНОМІКИ У СФЕРІ ПОВОДЖЕННЯ 3 ПОБУТОВИМИ ВІДХОДАМИ РЕГІОНУ
}

В статті розглянуто сучасні тенденції в сфері поводження 3 твердими побутовими відходами. Визначено стан накопичення та утилізації відходів у регіональному розрізі. Досліджено економічні інструменти в забезпеченні функціонування системи управління відходами регіону. Здійснено порівняльний аналіз тенденцій у розрізі регіонів західної частини країни. Запропоновано особисті бачення рішення щодо акселерації процесу трансформації сфери поводження з твердими побутовими відходами на модель кругової економіки.

Ключові слова: відходи, тверді побутові відходи, кругова економіка, полігон твердих побутових відходів, сміттєзвалище, тариф, економічні інструменти.

Fesina Yu., Dzyubynska O.

\section{PROSPECTS FOR FORMATION OF A CIRCULAR MODEL OF THE ECONOMY IN THE SPHERE OF MUNICIPAL SOLID WASTE MANAGEMENT OF THE REGION}

Now the circular economy allows to improve waste disposal, provides recovery of resources and reduction of places of waste accumulation. The implementation of such model in the regions of the country requires detailed analysis. The state of accumulation of waste in certain territories and the forms of interaction between the social and economic systems of the region should be studied.

The present system of municipal solid waste management in Ukraine is organized as follows: a separate collection of waste; waste removal; disposal of waste at landfills.

There is a complex problem related to insufficient coverage of of municipal solid waste collection and transportation services in the regions, mental lack of willingness to pay for waste collection and disposal, and low ecological culture of people. 
Економічні науки: збірник наукових праџь Луцького національного технічного університету. - Серія "Регіональна економіка". - Випуск 16 (63). - Редкол.: відп. ред. д.е.н., професор Л.Л. Ковальська - Луцьк : ІВВ Луцького НТУ, 2019. -173 с.

The regional waste management plan is the most important component in the waste management system. It should be considered as an opportunity for renaissance of economic complexes of depressed regions or diversification of business spheres of regions that are prosperous in social and economic areas.

The analysis of waste management in the region showed low regional potential for rapid formation of a circular model of the economy in the field of municipal solid waste. In our opinion, the main actors in this sphere are not ready, in which there should be a high interest in cooperation of ideas, thoughts and joint actions in the waste management system. It is a symptom of the long-term application of the linear economy model and the glorification of the consumption model. Therefore, they should be replaced by other principles in the waste management system: "extended responsibility for producers", "pay as you throw". The speed of the municipal solid waste transition to the model of circular economy should be ensured by the breadth of approaches to making complex management decisions, supported by investment infusions into the industry and innovative implementations.

In our view, the domestic waste processing sector should send a signal to investors that their attention should be directed here. Therefore, the task of both state and regional institutions should be aimed at creating favorable conditions for building business models by the private sector of the economy at all stages of waste management, proposing the concept of a new product design, etc.

The best option that will allow the sphere of municipal waste management to quickly switch to the model of circular economy will be possible with economic instruments.

Key words: waste, municipal solid waste, circular economy, landfill, municipal solid waste dump, tariff, economic tools.

\section{Фесина Ю.Г., Дзюбинская О.В. ПЕРСПЕКТИВЫ ФОРМИРОВАНИЯ ЦИКЛИЧЕСКОЙ МОДЕЛИ ЭКОНОМИКИ В СФЕРЕ ОБРАЩЕНИЯ С БЫТОВЫМИ ОТХОДАМИ РЕГИОНА}

\footnotetext{
В статье рассмотрены современные тенденции в сфере обращения с твердыми бытовыми отходами. Определено состояние накопления и утилизации отходов в региональном разрезе. Исследовано экономические инструменты в обеспечении функционирования системы управления отходами региона. Осуществлен сравнительный анализ тенденций в разрезе регионов западной части страны. Предложен личный взгляд относительно ускорения процесса трансформации сферы обращения с твердыми бытовыми отходами на модель круговой экономики.

Ключевые слова: отходы, твердые бытовые отходы, круговая экономика, полигон твердых бытовых отходов, свалка, тариф, экономические инструменты.
} 
Економічні науки: збірник наукових праџь Луцького національного технічного університету. - Серія "Регіональна економіка". - Випуск 16 (63). - Редкол.: відп. ред. д.е.н., професор Л.Л. Ковальська - Луцьк : ІВВ Луцького НТУ, 2019. -173 с.

\section{Постановка проблеми у загальному вигляді і ії зв'язок} з важливими науковими та практичними завданнями.

У відповідності до прогнозів Світового банку, до 2050 р. обсяги накопичення відходів у світі зростуть на $60 \%$, у свою чергу агентство Євростат відмічає, що нині в Європі залишається проблема із $24 \%$ муніципальних відходів, які все ще накопичуються на сміттєзвалищах [1]. Щодо України, то вона в світовому рейтингу накопичення відходів займає 9 місце, генеруючи за рік 474 млн т відходів, 3 яких 448 млн т небезпечні. За показником утворення небезпечних відходів Україна знаходиться на першому місці з поміж 105 країн, щодо яких доступна статистика про утворення небезпечних відходів. Тверді побутові та сільськогосподарські відходи становлять 26 млн т [2]. Середньорічний показник утворення побутових відходів на одну особу в країні становить 220-250 кг, а у великих містах - 330-380 кг [3].

Відтак, існує необхідність пошуку таких економічних підходів, які мінімізують негативний вплив на довкілля, забезпечують безвідходне виробництво. Такий тип економічної поведінки, який базується на відновленні та раціональному споживанні ресурсів, нині розвивається в світі й носить назву циклічної (кругової) економіки. Вона покликана зробити економічні моделі більш економічно вигідними та екологічно стійкими за рахунок активації функції відновлюваності. Це можливе через надання товарам, що повністю або частково втратили свої споживчі властивості, здатності бути трансформованими в ресурс для наступного циклу виробництва товарів.

Аналіз останніх досліджень, у яких започатковано вирішення проблеми. М. Хаупт, К. Ваденбо та С. Хельвег, досліджуючи показники ефективності циркулярної економіки на прикладі системи управління побутовими відходами Швейцарії відмічають про наявну проблему адекватної оцінки наявності вторинних ресурсів та інформації про їх кінцеве призначення [4].

Німецькі дослідники зазначають, що прийнятий в країні 
Економічні науки: збірник наукових праџь Луцького національного технічного університету. - Серія "Регіональна економіка". - Випуск 16 (63). - Редкол.: відп. ред. д.е.н., професор Л.Л. Ковальська - Луцьк : ІВВ Луцького НТУ, 2019. -173 с.

законодавчий акт про управління закритим циклом (Kreislaufwirtschaftsgesetz) орієнтований на трансформацію системи поводження 3 відходами в систему управління ресурсами. Іншими словами, мова йде про те, що відходи розглядаються як ресурс. Власне вся система управління відходами в Німеччині побудована на закритих циклах i відповідальності виробників та продавців продукції. Існуючі практики 3 переробки відходів та постійні інституційні поліпшення в цій сфері суттєво підвищили й рівень свідомості громадян. Це дало поштовх до впровадження нових технологій утилізації та збільшення потенціалу переробки [5].

В Україні середній коефіцієнт використання відходів як вторинної сировини, зазначає О. Пиріков, становить третину, що втричі нижче, ніж у європейських країнах. При цьому рівень переробки твердих побутових відходів становить біля 4-5\% [6].

Управлінню системою поводження 3 твердими побутовими відходами присвячене дисертаційне дослідження О. Білопільської. В роботі вона зазначає, що необхідність переходу до моделі циклічної економіки потребує трансформації організаційно-економічного механізму управління системою поводження 3 твердими побутовими відходами на різних рівнях, в тому числі й регіональному [7].

Підходи до класифікації побутових відходів, застосування принципів рециклінгу відходів, підвищення економікоекологічної ефективності рециклінгу висвітлено в дисертаційному дослідженні Т. Довгої [8].

Цілі статті. У контексті необхідності імплементації моделі кругової економіки в сферу поводження 3 побутовими відходами метою поточного дослідження $\epsilon$ аналіз стану накопичення відходів у регіональному розрізі та процесів пов'язаних із їх провадженням, вивчення передумов для реалізації згадуваної моделі на основі виявлених особливостей.

Виклад основного матеріалу дослідження 3 повним обгрунтуванням отриманих наукових результатів. Чинна система поводження 3 твердими побутовими відходами в країні переважно організована наступним чином: роздільне збирання 
Економічні науки: збірник наукових праџь Луцького національного технічного університету. - Серія "Регіональна економіка". - Випуск 16 (63). - Редкол.: відп. ред. д.е.н., професор Л.Л. Ковальська - Луцьк : ІВВ Луцького НТУ, 2019. -173 с.

відходів, яке немає комплексного охоплення як самих видів відходів, так і населених пунктів у яких воно застосовується; вивезення відходів; захоронення відходів на полігонах або сміттєзвалищах.

Так, якщо станом на 01.01.2017 р. в Україні налічувалося 460 міст, 885 селищ міського типу та понад 28 тис. сільських населених пунктів, то лише в 1181 населених пунктах було зорганізовано роздільне збирання побутових відходів. Систему обслуговує лише 26 сміттєсортувальних ліній, 1 сміттеспалювальний завод та 3 одиниці сміттєспалювальних установок. У 2018 р. в країні було перероблено та утилізовано біля 6,2 \% побутових відходів, 3 них: спалено - $2 \%$, на заготівельні пункти вторинної сировини потрапило 4,2 \%; на полігонах і сміттєзвалищах було захоронено близько $93 \%$ відходів. Слід зазначити, що станом на 2017 р. в Україні налічувалось 6 тис. одиниць полігонів та сміттєзвалищ загальною площею понад 9 тис. га [9, с. 8]. Для країни характерною є проблема створення стихійних несанкціонованих сміттєзвалищ. Це, на наш погляд, комплексна проблема, яка пов'язана 3 недостатніми обсягами охоплення населення в регіонах послугами із збирання та перевезення побутових відходів, ментальною неготовністю платити за збір та утилізацію відходів, низькою екологічною культурою людей.

Відмітимо, що в 2017 р. уряд затвердив Національну стратегію управління відходами в Україні до 2030 року [10]. Вона має на меті впровадження системного підходу до поводження 3 відходами на державному та регіональному рівнях, зменшення обсягів утворення відходів шляхом переходу від системи складування відходів на звалищах та полігонах до системи комплексного поводження 3 побутовими відходами, що в цілому передбачає збільшення обсягу їх переробки та повторного використання. Стратегія передбачає створення до 2030 p. 800 нових потужностей із переробки вторинної сировини, утилізації та компостування біовідходів, зменшення загального обсягу захоронення побутових відходів до $30 \%$. 
Економічні науки: збірник наукових праџь Луцького національного технічного університету. - Серія "Регіональна економіка". - Випуск 16 (63). - Редкол.: відп. ред. д.е.н., професор Л.Л. Ковальська - Луцьк : ІВВ Луцьккого НТУ, 2019. -173 с.

Аналізуючи заходи стратегії В. Стручок та Д. Мудра зазначають, що на першому та другому етапах іiі реалізації переважно будуть виконуватись організаційні, інструктивнометодологічні, управлінсько-структурні заходи, які вимагають виділення держбюджетних фінансових ресурсів [11]. При цьому дослідники стратегії зазначають, що у відповідності до національного плану реалізації стратегічних міроприємств повинні бути розроблені регіональні плани управління відходами. Додамо, що якщо стратегія була прийнята в листопаді 2017 р., то національний план управління відходами був прийнятий в лютому 2019 р., а методичні рекомендації для розробки регіональних планів управління відходами - в квітні 2019 р., що, на наш погляд, було певним зволіканням в умовах актуальності та масштабності проблеми.

Регіональний план управління відходами $є$ найбільш вагомою складовою в системі управління відходами. Адже він покликаний в режимі реального часу розв'язувати проблему на місцях 3 побутовими відходами, вирішувати питання 3 диверсифікацією джерел фінансування інвестицій у цю сферу, інтегрувати інституції місцевого самоврядування, територіальні громади, бізнес та інших зацікавлених агентів на основі спільної проблематики. Такий план слід розглядати як місцеву ініціативу надати нового імпульсу для ренесансу господарських комплексів депресивних регіонів чи диверсифікації сфер бізнесу регіонів, які благополучні у соціально-економічному плані. Реально з'являється нова ніша, яка раніше не розглядалася як перспективна й відсутність фокусу уваги до неї призводило, й поки що надалі призводить, до втрати цінних ресурсних матеріалів, які містяться у відходах. Зрештою це, нарешті, вирішить проблему архаїчності техніко-технологічного комплексу економіки регіонів, адже змушуватиме шукати інноваційні технологічні рішення в сфері переробки відходів, отрмання нових матеріалів та продуктів на їх основі. Нy, i звичайно екологічний фокус не залишається поза увагою бізнесу, адже автоматично ми отримаємо інструментарій для мінімізації накопичення відходів, збереження площ земель, які 
Економічні науки: збірник наукових праиь Луиького національного технічного університету. - Серія "Регіональна економіка". - Випуск 16 (63). - Редкол.: відп. ред. д.е.н., професор Л.Л. Ковальська - Луцьк : ІВВ Луцького НТУ, 2019. -173 с.

відводяться в сферу обслуговування відходів через виконання функції полігонів чи сміттєзвалищ. Зазначимо, що на основі регіонального плану мають складатися місцеві плани (плани ОТГ).

Серед регіонів західної частини країни Волинська область демонструє чітку тенденцію росту рівня утилізації відходів (рис. 1). Хоча відносний рівень утилізації відходів в ІваноФранківській та Чернівецькій областях $є$ вищим, але за досліджуваний період він має тенденцію знижуватися. Протягом 2015-2017 рр. спостерігався також ріст рівня утилізації відходів у Львівській області. Найбільші обсяги утворення відходів мають місце в Львівській, Івано-Франківській та Тернопільській областях. Відповідно, найбільш забрудненими територіями $\epsilon$ Івано-Франківська та Тернопільська області, де на $1 \mathrm{~m}^{2}$ площі регіону припадало в 2018 р. відповідно 141,4 т та 119,5 т відходів. Протягом 2015-2017 рр. спостерігався високий рівень забруднення Львівської області, але в 2018 р. він дещо знизився. Найменш забрудненою є Закарпатська область, де в 2018 р. припадало 14,6 т відходів на 1 м² площі. В цілому по Україні в 2018 р. на 1 м $^{2}$ площі території в середньому припадало 611,1 т відходів, що в 4,3 рази більше, ніж в Івано-Франківській області. Зазначимо, що протягом 2015-2018 років стійкі темпи росту утворення відходів на $1 \mathrm{~m}^{2}$ площі території спостерігаються в Закарпатській та Тернопільській областях. Для останньої це носить загрозливий характер, оскільки область знаходиться у переліку найбільш забруднених у західному регіоні країни.

У Волинській області функціонує унітарна система збирання твердих побутових відходів, при якій всі побутові відходи збираються в одну ємність, а далі транспортуються й захороняються на сміттєзвалищах чи полігонах. Така система не дозволяє чітко відокремлювати вторинну сировину. Внаслідок цього на сміттєзвалища та полігони потрапляє значна кількість ресурсів, які можуть потрапляти в переробку (папір, картон, скло, метал). Зазначимо, що система роздільного збирання відходів в досліджуваній області реалізується частково. Нею охоплено лише відходи ПЕТ-пляшки. В систему роздільного 
Економічні науки: збірник наукових праџь Луцького національного технічного університету. - Серія "Регіональна економіка". - Випуск 16 (63). - Редкол.: відп. ред. д.е.н., професор Л.Л. Ковальська - Луцьк : ІВВ Луцького НТУ, 2019. -173 с.

способу збирання побутових відходів в області включено близько $9 \%$ населення. При цьому навіть у тих населених пунктах, де впроваджена система розділення відходів існує проблема $100 \%$ ï розділення. Адже спеціальними сепаративними контейнерами облаштовані переважно площадки для збору сміття поблизу багатоквартирних будинків, а сектор індивідувальної забудови практично ними не забезпечений.

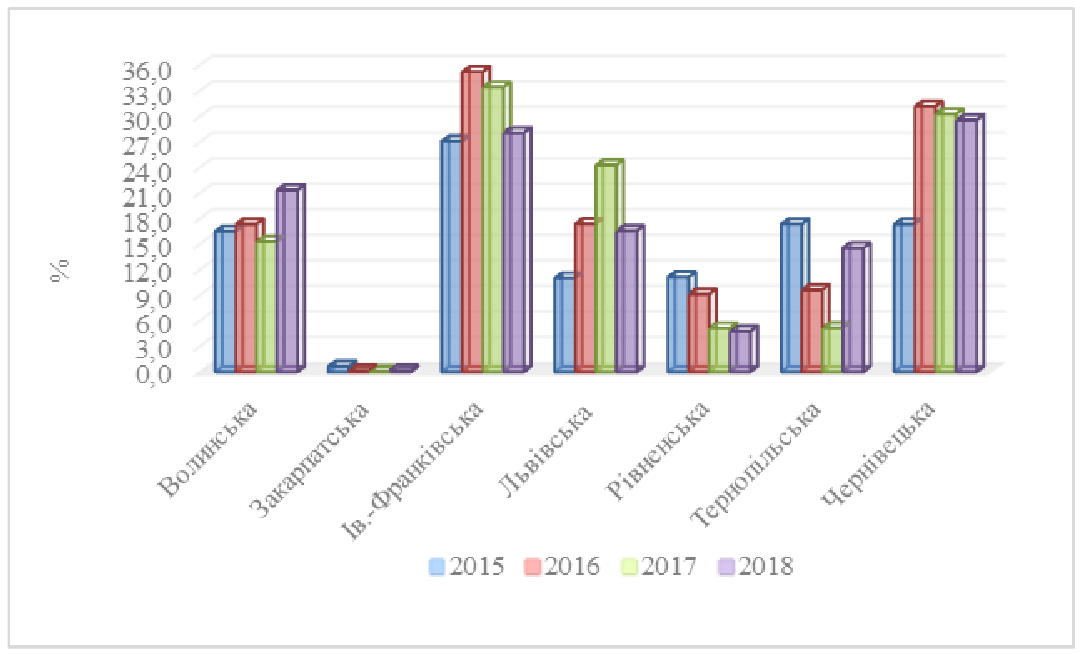

Рис. 1. Стан та динаміка рівня утилізації відходів

Джерело. Розраховано та складено на основі: Статистичний збірник «Довкілля України за 2018 рік» / За ред. О. М. Прокопенко. Київ, 2019. 214 с.

Проблеми додає також те, що не всі жителі регіонів західної частини країни охоплені послугами зі збирання твердих побутових відходів. Так, у 2018 р. найвищий рівень охоплення спостерігається у Чернівецькій та Львівській областях - 92,5 та 92 відсотки відповідно, а найнижчий у Волинській, Тернопільській та Рівненській областях - 61, 66 і 74,8 відсотки відповідно. В цілому по Україні збором побутових відходів охоплено в середньому $77,7 \%$ населення. 
Економічні науки: збірник наукових праџь Луцького національного технічного університету. - Серія "Регіональна економіка". - Випуск 16 (63). - Редкол.: відп. ред. д.е.н., професор Л.Л. Ковальська - Луцьк : ІВВ Луцького НТУ, 2019. -173 с.

Слід відзначити позитивну динаміку обсягів захоронення твердих побутових відходів на полігонах і звалищах Волинської області. Так, у 2015 р. було доставлено на об'єкти захоронення 0,96 млн м ${ }^{3}$ побутових відходів, у 2016 р. - 1 млн м³ 2017 р. 1,05 млн м³, а в 2018 р. - 1,17 млн м³. Таким чином, у середньому щорічний ріст обсягів відходів, які розміщуються на спеціально відведених для цього місцях становить $7 \%$.

На Волині експлуатується 11 полігонів твердих побутових відходів (функціонує 10 об'єктів) розміщених поблизу міст та селищ і 547 сміттєзвалищ у сільських населених пунктах (3 них функціонує 540 об'єктів). Основна відмінність полігонів від сміттєзвалищ відходів полягає в тому, що перші повинні запобігати негативному впливу на навколишне природне середовище, відповідно бути оснащеними системами захисту грунтових вод, вилучення та знешкодження біогазу та фільтрату. Відзначимо, що серед регіональних полігонів твердих побутових відходів більшість мають із цим проблему. Так, на ряді полігонів - смт. Стара Вижівка (площа полігону 1,2 га), смт. Любешів (4,6 га), с. Привітне Локачинського району (4,17 га), смт. Торчин Луцького району (2 га) та м. КаміньКаширський (2 га), відсутні системи збору та знезараження фільтрату та вилучення й утилізації газу. На полігоні смт. Шацьк (2,36 га) працює лише система збору та знезараження фільтрату. Щодо системи вилучення та утилізації газу, то когенераційна установка функціонує лише на полігоні поблизу м. Ковель. На інших полігонах відсутній навіть спосіб факельного спалюювання газів, що утворюються на полігоні. Зазначимо, що для полігону в смт. Любешів, який експлуатується 31992 р. (потужність за проектом - 60 тис м² відходів), існує проблема перенавантаження.

Щодо сміттєзвалищ, то в смт. Маневичі та с. Цегів Горохівського району сміттєзвалища потребують проведення рекультивації. Останнє вже майже вичерпало свій ресурс за вмістом відходів та $\epsilon$ екологічно небезпечним, оскільки знаходиться у безпосередній близькості до зони житлової забудови. Сміттєзвалище розташоване на площі 4 га та 
Економічні науки: збірник наукових праџь Луцького національного технічного університету. - Серія "Регіональна економіка". - Випуск 16 (63). - Редкол.: відп. ред. д.е.н., професор Л.Л. Ковальська - Луцьк : ІВВ Луиького НТУ, 2019. - 173 с.

експлуатується з 1962 р. Маючи проектну потужність 130 тис. т тут уже накопичено 120 тис. т відходів від початку його експлуатації при показнику річної потужності 1,7 тис. т. Зазначимо, що проект будівництва в цьому населеному пункті вже полігону, а не сміттєзвалища було розроблено ще в середині 90-х років XX ст., а в 2013 р. було проектно-кошторисну документацію оновлено й наприкінці 2018 р. виділено фінансові ресурси $з$ фонду регіонального розвитку та бюджету міської ради районного центру на облаштування нового звалища. Проте, роботи по будівництву були заблоковані місцевою громадою села, адже земельна ділянка, виділена для будівництва сміттєзвалища, знаходиться в безпосередній близькості до підземних водних горизонтів та лісового масиву, який виконує рекреаційну функцію на відстані 4 км до населеного пункту. Цей випадок демонструє наскільки недоцільною є нинішня політика підтримки старої системи поводження 3 побутовими відходами. Водночас громади усвідомлюють екологічні ризики, проте не пропонують альтернатив для вирішення проблеми переробки відходів. Адже в кожному окремому випадку це проблема локального характеру й ініціатива повинна йти звідси.

Враховуючи існуючий стан полігонів та сміттезвалищ у регіоні, які несуть соціально-екологічні ризики та високі економічні витрати на їх підтримку та експлуатацію, доцільно звернуться до національної стратегії управління відходами, яка одним із пріоритетів виділяє необхідність формування мережі нових санітарних регіональних полігонів для захоронення твердих побутових відходів. Це має бути кластерний підхід, що передбачає оптимізацію зони управління відходами. Мінімальна річна потужність полігону має становити близько 50 тис. т відходів, оптимальна - 100 тис. т на не менше, ніж 150 тис. осіб населення. Таким чином, у Волинському регіоні повинно бути не менше 4-5 нових, відповідних світовим стандартам будівництва та експлуатації, полігонів твердих побутових відходів. Теперішня задача місцевих державних адміністрацій та органів місцевого самоврядування - інституцій регіональної системи менеджменту відходів, полягає в перспективному 
Економічні науки: збірник наукових праџь Луцького національного технічного університету. - Серія "Регіональна економіка". - Випуск 16 (63). - Редкол.: відп. ред. д.е.н., професор Л.Л. Ковальська - Луцьк : ІВВ Луцького НТУ, 2019. -173 с.

напрацюванні орієнтовних місць розташування полігонів із врахуванням чисельності адімністративних одиниць районів у контексті нової адміністративної реформи, площ земельних ділянок, які можуть бути виділені та транспортної логістики відходів.

Певну проблему створюють несанкціоновані звалища відходів в області. Якщо в 2016 р. було виявлено та ліквідовано 985 одиниць таких звалищ, то в 2017 р. - 813 одиниць, а в 2018 р. - 1100 одиниць, які обіймали площу в 8 га.

Окремої уваги заслуговують тарифи на поводження 3 побутовими відходами. У Волинській області вони $є$ найнижчими (табл. 1).

Таблиця 1

Порівняльна характеристика рівня тарифів на поводження 3 відходами

\begin{tabular}{|c|c|c|c|c|c|c|}
\hline \multirow[t]{2}{*}{$\begin{array}{c}\text { Адміністративні } \\
\text { області }\end{array}$} & \multicolumn{3}{|c|}{$\begin{array}{c}\text { Середній тариф на } \\
\text { поводження } 3 \text { твердими } \\
\text { побутовими відходами в } \\
2018 \text { р., грн./м }\end{array}$} & \multicolumn{3}{|c|}{$\begin{array}{c}\text { Темп росту тарифу } \\
\text { (2018 p./2017p.) }\end{array}$} \\
\hline & Населення & $\begin{array}{c}\text { Бюджетні } \\
\text { організації }\end{array}$ & Інші & Населення & $\left|\begin{array}{c}\text { Бюджетні } \\
\text { організації }\end{array}\right|$ & Інші \\
\hline Волинська & 66,7 & 61,5 & 80,4 & 1,273 & 1,124 & 1,338 \\
\hline Закарпатська & 127,5 & 157,6 & 165,1 & 1,129 & 1,169 & 1,091 \\
\hline Ів.-Франківська & 107,7 & 126,8 & 142,1 & 1,583 & 1,573 & 1,505 \\
\hline Львівська & 130,9 & 170,5 & 190,3 & 1,050 & 1,050 & 1,050 \\
\hline Рівненська & 87,84 & 93,51 & 106,04 & 1,185 & 1,190 & 1,161 \\
\hline Тернопільська & 115,36 & 110,7 & 114,28 & 1,526 & 1,368 & 1,327 \\
\hline Чернівецька & 74,87 & 80,47 & 85,6 & 1,238 & 1,077 & 1,004 \\
\hline $\begin{array}{l}\text { В середньому по } \\
\text { країні }\end{array}$ & 87,353 & 102,092 & 116,654 & 1,273 & 1,235 & 1,273 \\
\hline
\end{tabular}

Джерело: складено та розраховано за даними Міністерства розвитку громад та територій України

Найвищі тарифи на поводження 3 відходами в 2018 р. спостерігаються Львівській, Закрапатській, Івано-Франківській та Тернопільській областях. Порівняно низьким є тариф і у Чернівецькій області. В 2018 р. у співставленні з 2017 р. в усіх 
Економічні науки: збірник наукових праџь Луцького національного технічного університету. - Серія "Регіональна економіка". - Випуск 16 (63). - Редкол.: відп. ред. д.е.н., професор Л.Л. Ковальська - Луцьк : ІВВ Луиького НТУ, 2019. - 173 с.

регіонах західної частини країни мало місце зростання величини тарифів. За розглядуваний період вони лишилися практично незмінними у Львівській області. Водночас у Волинській області серед регіонів західної частини країни за період 2017-2018 рр. тариф на захоронення відходів мав найбільш суттєвий ріст - в понад два рази для населення та бюджетних установ та втричі - для інших продуцентів відходів. Тому на рівні Волинської області слід переглянути політику тарифоутворення в цій сфері, адже це порушує економічну основу роботи підприємств, які займаються логістикою відходів. Зазначимо, що, наприклад, в 2016-2017 рp. рівень зносу спецавтотранспорту цього регіону по збору й перевезенню відходів становив $80 \%$, а в 2018 р. його вдалося дещо понизити - до $70 \%$, що також є досить високим рівнем.

Пункти по прийому вторинної сировини (пластик, скло, макулатура, метал) у Волинській області налагоджені лише у містах обласного значення та в районних центрах.

Висновки. Проведений експрес-аналіз стану поводження 3 відходами засвідчив про низький регіональний потенціал для швидкого формування циклічної моделі економіки в сфері поводження 3 твердими побутовими відходами. На наш погляд, не готовими є основні актори в цій сфері, у яких має проявитися високий інтерес до кооперації ідей, думок та головне спільних дій в системі поводження 3 відходами. Можна сказати, що це симптоматика тривалого застосування моделі лінійної економіки та глорифікації моделі споживання. Тому на зміну повинні прийти інші принципи в системі управління відходами: «розширена відповідальність виробника», «плати за те, що викидаєш» тощо. Швидкість переходу сфери поводження 3 побутовими відходами на модель кругової економіки має бути забезпечена широтою підходів до прийняття комплексних управлінських рішень, підкріплена інвестиційними вливаннями у галузь та інноваційними впровадженнями.

Дійсно, чим регіони нині достатньо забезпечені, так це ресурсоцінним потенціалом побутових відходів. Тому слід орієнтуватися на ці конкретні ресурсні цілі. 3 нашої точки зору, 
Економічні науки: збірник наукових праџь Луцького національного технічного університету. - Серія "Регіональна економіка". - Випуск 16 (63). - Редкол.: відп. ред. д.е.н., професор Л.Л. Ковальська - Луцьк : ІВВ Луцького НТУ, 2019. -173 с.

сектор переробки побутових відходів має надати сигнал інвесторам про доцільність спрямування сюди своєї уваги. Тому задача як державних, так i регіональних інституцій має спрямовуватися на те, щоб створити сприятливі умови для побудови бізнес-моделей приватним сектором економіки на всіх стадіях поводження 3 відходами, запропонувати концепцію нового продуктового дизайну тощо. Перші кроки в цьому плані вже зроблено, адже нині законодавчо передбачено впровадження нових інститутів, які сприятимуть комплексному обслуговуванню споживачів через інтеграцію суб'єктів збору та транспортування відходів із суб'єктами сфери їх утилізації чи переробки. Відповідальність у сфері роздільного збору відходів має бути розділена між компаніями, які надають послуги зі збору та вивезення сміття та споживачами таких послуг. Разом iз цим слід вести мову про доступність логістичної системи поводження з відходами для всіх отримувачів послуг.

Модель кругової економіки в сфері поводження 3 побутовими відходами має також розглядатися як додатковий канал енергетичної диверсифікації країни на локальному рівні й відповідним чином підтримуватися державою та місцевими органами самоврядування в плані співучасті у фінансуванні поширення інноваційних рішень перетворення відходів у джерело енергії. Доцільним буде запровадження механізмів держбюджетних компенсацій відсоткових ставок у випадку залучення позикових коштів регіональними інституціями на будівництво, експлуатацію сучасних полігонів побутових відходів. Потребує також свого вирішення й питання оновлення транспортного парку та тарних матеріалів для роздільного збору відходів із поширенням лізингових схем.

Таким чином, найкращий, на наш погляд, варіант, який дозволить сфері поводження з побутовими відходами відносно швидко перейти на модель кругової економіки можливий саме через економічний інструментарій.

1. ESWET: Vision for Waste-to-Energy 2050. URL: https://www.recyclingmagazine.com/2019/09/25/eswet-vision-for-waste-to-energy-2050/ (дата звернення 07.12.2019). 
Економічні науки: збірник наукових праџь Луцького національного технічного університету. - Серія "Регіональна економіка". - Випуск 16 (63). - Редкол.: відп. ред. д.е.н., професор Л.Л. Ковальська - Луцьк : ІВВ Луиького НТУ, 2019. - 173 с.

2. Hristina Byrnes, Thomas C. Frohlich. Canada produces the most waste in the world. URL: https://www.courier-journal.com/story/money/2019/07/12/canadaunited-states-worlds-biggest-producers-of-waste/39534923/ (дата звернення 07.12.2019).

3. Методичні рекомендації розумного управління відходами спільнот : посібник. 2017. 42 c.

4. Haupt Melanie, Vadenbo Carl, Hellweg Stefanie. Do We Have the Right Performance Indicators for the Circular Economy?: Insight into the Swiss Waste Management System. Journal of Industrial Ecology. 2016. URL: https://doi.org/10.1111/jiec.12506 (дата звернення 07.12.2019).

5. Nellesa M., Grünesa J., Morschecka G. Waste Management in Germany Development to a Sustainable Circular Economy? International Conference on Solid Waste Management (5IconSWM 2015). Bangalore, India. 24-27 November 2015. Procedia Environmental Sciences. Volume 35. P. 6-14. URL: https://www.researchgate.net/publication/305892463 Waste Management in Germ any_-_Development_to_a_Sustainable_Circular_Economy (дата звернення 07.12.2019).

6. Пиріков О.В. Сучасний рециклінг твердих побутових відходів: економіко-екологічні аспекти. Науковий вісник Херсонського державного університету. Серія економічні науки. Випуск 9-1. Частина 1. 2014. С. 70-75.

7. Білопільська О.О. Еколого-економічні основи управління системою поводження $з$ твердими побутовими відходами : автореф. дис. ... канд. екон. наук : 08.00.06. Суми, 2014. 20 с.

8. Довга Т.М. Економіко-екологічна ефективність рециклінгу твердих побутових відходів : автореф. дис. ... канд. екон. наук : 08.00.04. Київ, 2014. 20 с.

9. Матвєєв Ю.Б., Гелетуха Г.Г. Перспективи енергетичної утилізації твердих побутових відходів в Україні. Аналітична записка № 22. Біоенергетична асоціація України, 2019. 48 с.

10. Про схвалення Національної стратегії управління відходами в Україні до 2030 року : розпорядження Кабінету Міністрів України від 08.11.2017 p. № 820-p. Дата оновлення: 20.02.2019. URL: https://zakon.rada.gov.ua/laws/show/820-2017-p (дата звернення: 08.12.2019).

11. Стручок В., Мудра Д. Аналіз національної стратегії управління відходами в Україні до 2030 року щодо проведення інфраструктурних заходів 3 перероблення твердих побутових відходів. Фундаментальні та прикладні проблеми сучасних технологій : матеріали Міжнародної науково-технічної конференції. Тернопіль, 2018. С. 292-293.

12. Про затвердження Порядку формування тарифів на послуги 3 поводження 3 побутовими відходами : постанова Кабінету Міністрів України від 26.07.2006. № 1010. Дата оновлення: 27.03.2019. URL: https://zakon.rada.gov.ua/laws/show/1010-2006-п (дата звернення: 09.12.2019). 